\title{
Psychosocial Risk Factors from the Perception of Women Researchers Belonging to the SNI
}

\author{
Blanca Estela Aarun Lopez, MA \\ Universidad Popular Autónoma del Estado de Puebla, México \\ Ana Maria Alejandra Herrera Espinosa \\ $\mathrm{PhD}$, Full-Time Researcher. Project Director \\ Interdisciplinary Center for Graduate Studies, Research and Consulting \\ Universidad Popular Autónoma del Estado de Puebla, México
}

Doi: 10.19044/esj.2018.v14n14p121 URL:http://dx.doi.org/10.19044/esj.2018.v14n14p121

\begin{abstract}
This investigation had the objective to identify the perception of women holding $\mathrm{PhD}$ degrees awarded by the National Researchers System (SNI) regarding five work environment psychosocial risk factors, stress, burnout, mobbing, work-family integration and gender. A qualitative research was performed involving six female researchers working in either public or private institutions. A content analysis technique was used to process the information procured through a semi-structured interview. Work-related stress was found to be part of their lives determined by excess of work with subsequent physical and emotional manifestations; burnout and mobbing were not a constant as not all had experienced them; work-family integration had not been achieved, often resulting in conflict particularly at a certain stage of life when children were young; and, finally, with regard to gender, there were negative stereotypes concerning the role in their field of research.
\end{abstract}

Keywords: Psychosocial work factors, gender, researchers in the SNI

\section{Introduction}

One of the features that describe the evolution of the Mexican labor market is the increase in the number of women that have been incorporated into paid work and academic education. According to the World Bank Group (ILO, 2014) for the year 1990, 34.29\% of women over the age of 15 years represented the rate of female active population. That number increased by the year 2014 representing $45.09 \%$. In comparison, the rate of active male population over the age of 15 years for the year of 1990 was $83.90 \%$ and for the year of 2014 this number reduced to $79.90 \%$. 
In Mexico, according to figures from the National Institute of Statistics and Geography (INEGI) for the year 2015: 1,634,184 men completed a university degree; in the case of women 1,522,785 had completed the same degree. In regards to a graduate degree: 113,396 were men and 123,697 women. The above figures show an increasing presence of women both in the field of education and at work; however, it has not yet been possible to achieve work related gender equality in the academic field.

In Mexico, the agency that brings together researchers is the National System of Researchers (SNI) belonging to the National Council of Science and Technology (CONACYT) (Cárdenas, 2015). This agency was created in 1984 proposing a new professional profile of the "Mexican/researcher" in order to generate scientific and technological production of high quality at an international level; that guiding the researchers training in this field toward the specialized human talent. The purpose of this system is recognize and monetarily encourage the scholar who produce scientific and technological knowledge (Mendoza, 2015).

In the comparative figures between men and women belonging to the SNI, there are two considerations to be observed: (a) the presence of women in this area has been constantly increasing over the last years; (b) however, the participation gap between men and women still exists. According to figures of the Consultative Forum for Scientific and Technological Advice (FCCYT) (2016), men constituted $64 \%$ of the total number of researchers, while women only $36 \%$.

In this regard, Guevara and Medel (2012) assert that:

...the full incorporation of women in science it is not only a matter of social justice but an economic necessity given the loss of competitiveness that represent for a lot of countries not to consider the intellectual potential of women to increase their number of researchers (p. 37).

It is therefore necessary to study the perspective of women and how stress, burnout, mobbing, work-family integration and gender affects them in their role as researchers belonging to the SNI.

\section{Stress}

Del Hoyo and Ángeles (1997) define labor stress as: “...a physiological, psychological and behavioral response of a person who tries to adapt and adjust to internal and external pressures" (p.6). In addition, they referred that, "the stress arises when there is a mismatch between the person, the job and the organization itself. The person perceives that they do not have enough resources to cope with labor problems and the experience of stress" (p.6). This is manifested through various symptoms and may be reflected in 
four dimensions of the person: emotional, cognitive, behavioral, and physiological.

\section{Burnout}

Maslach and Jackson (1981) define burnout as: “... a syndrome of emotional exhaustion, depersonalization and a perception of reduced personal accomplishment which can occur to persons whose job involved working in contact with people" (Juárez-García, et al., 2014, p. 160).

This syndrome begins to manifest because of excessive work resulting in states of fatigue and anxiety, demoralization and motivation wear-off in the workplace, as well as loss of the vocation (Díaz et al., 2005). However, according to Quiceno and Vinaccia (2007) the main feature of burnout is the lack of emotional and cognitive motivation that precedes the abandonment of interest, in this case, tasks that are performed in their work field. This is not identified in primary instance with the overload of work.

\section{Work family integration}

This psychosocial work factor has been approached from three different conceptions: "work-family balance", "work-family conflict" and finally "work-family integration".

The work-family balance refers to the organization the person has to maintain in balanced the family life with the working life. However, Jimenez and León (2010) refer to this concept as "work-family conflict" and define it as the inability to maintain the balance in both contexts, they also mention that such disability generates in the person problems in organizing their time and a personal imbalance resulting in a disruption and conflict manifested in their behavior. These conflicts have implications both in the labor field of the person and in their family relationships, two of the most important areas of the people.

\section{Mobbing}

At present day, in the workplace we can define the concept of mobbing as:

Mobbing is a scientific term that describes an individual or group behavior that establishes relations of harassment between two or more members of a work team. Such situation creates a climate of hostility and violence between bully and victim. This, can complicate and, can irreversibly, impair the performance and health of workers (Trujillo et al, 2007, p. 72).

In addition, Del Pino said that:

The concept of mobbing or psychological harassment at workplace refers to an expression of extreme violence which consist in a series of repetitive hostile actions of psychological harassment within the work (p. 99). 
This type of behavior in many cases go unnoticed because the acts of violence and hostility are psychological and therefore intangible, this makes mobbing difficult to detect and stop. Shuster (1996) considers that the harassment is one of the most devastating experiences a human being can live and distinguishes between two situations within this context: social rejection and social neglect (quoted from De Rivera, 2003). Both of these situations generate unpleasant feelings in the person and diminished its performance in the workplace.

Piñuel (2001) points out that mobbing has a purpose and this is the forced departure of the victim of his job, this through the continuous and deliberate verbal abuse by one or more individuals within the organization seeking psychological destruction of the victim or simply to take advantage of the social situation and in this way to establish a certain hierarchy or reputation among the other people who serve as observers of such acts.

\section{Gender}

At present day, the workplace is not exempt from the belief of the alleged differences in terms of skills between men and women for different jobs, forms of discrimination against women remains. When talking about issues of gender discrimination in the labor area is imminent to talk of the studies that have been done over the years to determine whether there are differences in the performance between men and women.

The differences that are perceived are based on stereotypes that grouped women on one hand with certain characteristics and men on the other with opposite characteristics. Thus, if the leadership positions are culturally associated with male roles this will be valued positively to a man who intends to occupy and valued negatively as a characteristic in a woman believing she is unable to exercise it properly.

That perception is also true in the area of research and academy where there appears to be a "hidden curriculum", as Sánchez (2010) mention. This author says that female scholars have to deal with at least five challenges:

1. Overcome the hidden curriculum of gender.

2. Be evaluated by systems of incentives and professional promotion incompatible with family life.

3. Overcome the isolation by disciplinary specialization that is not in fashion or might mean a questioning of the mechanisms of power.

4. Overcome the "ceiling glass" to assume and to combine daily life with both administrative and academic hierarchy.

5. Increase its presence in the areas of sciences which enjoy of greater academic prestige, compared with other areas where there is greater female presence as in the case of the social sciences and humanities (p. 161). 


\section{Methodology}

Considering the study topic, a qualitative approach was chosen and performed using semi-structured interviews with an exploratory and descriptive scope. The existing theory and the results obtained were compared in order to draw an accurate and deep description of the phenomenon under studying focusing on understanding the phenomena, exploring them from the perspective of the participants in a natural environment and in relation to its context. In this type of studies are not used standardized tools or a priori categories are established, the raw material is composed by the narratives and aim to document an experience or event in depth or to understand a phenomenon from the perspective of those who live or lived and therefore these studies are not intended to any generalization (quoted in Hernández Sampieri et al, 2014).

\section{Participants}

The participants were six female researchers at SNI, four of whom work in private universities and two in public universities within the city of Puebla, Mexico.

\section{Instrument}

A 28-question semi-structured interview was employed. The first part consisted of a series of questions to collect socio-demographic data. The second part enquired about five psychosocial work factors labeled as categories with their respective subcategories, expressly labor stress, burnout, work-family integration, mobbing and gender, then submitted to five judges specializing in the area to evaluate the validity of the construct.

The judges made observations, comments and suggestions with respect to each question, based on which revisions, changes and adjustments to the instrument were performed. Finally, a pilot interview was conducted and, based on the observations and results gathered, refining adjustments to the questions in the instrument were considered appropriate.

\section{Procedure}

An invitation was sent by e-mail to 20 female researchers involved in different levels at SNI and working in different academic areas in public and private educational institutions within the city of Puebla, six of whom agreed to participate. The interviews were conducted under assurance of confidentiality that no information would be disclosed. The first interview was considered as pilot in order to validate the questions. Subsequently, the rest of the interviews were conducted and the recordings transcribed.

A content analysis was performed by means of a reading of the interviews, chiefly to the purpose of analysis. The ensuing responses were 
sifted into categories, thus identifying emerging subcategories as part of the qualitative research. Later, an open codification process was created using the Atlas program version 8.0 as the main tool.

\section{Results}

This section describes the responses collected in each category and subcategory of study including the descriptors presented in descending order per level of frequency.

Table 2. Results by Category

\begin{tabular}{|c|c|c|}
\hline Category & Sub Category & Descriptors and Frequency \\
\hline \multirow[t]{3}{*}{ Stress } & Labor demands & -Workload (7) \\
\hline & Manifestations & $\begin{array}{c}\text {-Emotional (4) (irritability) } \\
\text {-Cognitive (4) (lack of concentration, fatigue) } \\
\text {-Physiological (4) (stomach pain, headache, body } \\
\text { tension) }\end{array}$ \\
\hline & Way to handle it & $\begin{array}{c}\text {-Talk about it (3) (emotional) } \\
\text {-None (2) } \\
\text {-Do the work (2) } \\
\text {-Exercise (2) (physics) } \\
\text {-Set Limits (1) (emotional) } \\
\text {-Move away from the place of work (1) (emotional) }\end{array}$ \\
\hline Burnout & $\begin{array}{l}\text { Emotional } \\
\text { Reduced personal } \\
\text { accomplishment }\end{array}$ & $\begin{array}{l}\text {-Emotional Exhaustion (5) } \\
\text {-Motivation wear-off (5) } \\
\text {-Depersonalization (2) }\end{array}$ \\
\hline Mobbing & Social rejection & $\begin{array}{l}\text {-To reduce the occupation of the victim and } \\
\text { employability through the discrediting of unfounded } \\
\text { criticism (5) } \\
\text {-To prevent the possibility of maintaining social } \\
\text { contacts (1) } \\
\text {-Professional Disqualification (1) }\end{array}$ \\
\hline $\begin{array}{l}\text { Work-family } \\
\text { integration }\end{array}$ & $\begin{array}{l}\text { Balance } \\
\text { Conflict }\end{array}$ & $\begin{array}{c}\text {-Family Support (6) } \\
\text {-Lack of support on the part of the institution in } \\
\text { which they work to achieve the integration of work } \\
\text { and family areas (5) } \\
\text {-Neglect of family and/or social activities due to } \\
\text { labor demands (5) } \\
\text {-Balance between work and family (4) } \\
\text {-Flexibility and satisfaction with working hours (4) } \\
\text {-Integration of activities and/or time between work } \\
\text { and family areas (4) }\end{array}$ \\
\hline Gender & $\begin{array}{l}\text { Stereotype } \\
\text { Division } \\
\text { Equity }\end{array}$ & $\begin{array}{c}\text {-Negative (4) } \\
\text {-Feminine (3) } \\
\text {-Discrimination (2) }\end{array}$ \\
\hline
\end{tabular}

Source: Own elaboration. 


\section{Stress}

In this category, the highest frequency is headed by the subcategory of work load. The researchers pointed out that the highest stress factor was the amount of work, particularly emphasizing two issues, to wit administrative work as a part of their routine tasks, and that done as members of the SNI accruing to excess of work requiring substantial time and energy expenditure. Follow the comments of the participants:

E1: “...I believe it's administrative work... Because my work is to research, isn't it? ...It is the administrative part... the one that I have to do, but I am not supposed to do...".

E2: "The excess of work. I mean, I can do everything but I need a lot of time to do it all... it causes me a lot of stress and combined with the fact that I have a son... and the burden of the SNI. For instance, they are going to evaluate me in January so it's not that they demand I do different things other than that', but there are a lot of things to do. So it is hard to concentrate...".

\section{The way to handle stress}

In this subcategory the tools found investigators use to cope with stress, from high to low frequency, were talking, either to colleagues, family or friends, or with the person involved in the situation; waiting for the discomfort to dissipate as some researchers realize that they don't have many ways to handle stress; catching up with work; exercising; setting limits; distancing from the situation until they feel more at ease; and, lastly, seeking a doctor's advice to lessen their physical symptoms. The following responses illustrate this:

E2: "Taking a deep breath because I do not have much of a choice."

E6: "I don't even have a moment to relax. Well, er... I do a bit of exercise when I get home and that helps... what I have already done is go to physical therapy as well as chiropractors... in that matter I try to be disciplined because it works for me. Now the pain is less; I feel better and I perform better at work too."

\section{Burnout}

In this category we found two high frequency descriptors such as emotional exhaustion and a pop-up descriptor that was called "motivation wear-off". Regarding emotional exhaustion, the researchers commented that work overload had generated both emotional and physical exhaustion. These answers illustrate the above:

E1: "Sometimes, that's the truth... I have felt this way precisely since the publication of those books... they meant like seven years of work and concern because I could not finish the project. Now I have the renewal of the 
SNI, er... Well I have finished, the books came out and I did things for the SNI like the evaluation and since then I have had this mental fatigue".

E3: "Yes... yes I've had them... there are moments when, well, I feel totally exhausted... I think that is a combination ... yes, of work load.... but also, this... of the laboral situation, more than anything else... like these things about paperwork and all that..."

Touching on the "motivation wear-off" sub-category, they thought it would be due to external factors such as negative comments by others regarding their line of work, or doing tasks they considered below their knowledge, skills or abilities. They also considered the poor performance of their students as a source of demotivation. Their comments:

E2: “...I think it is because of two issues... sometimes when students submit things so poorly done such as homework or tasks, you say: "Gee, not even because we're here" ... Now I realize that more often do students come ill prepared... and every time I give less class material and I teach in a more superficial way because students do not come well prepared."

E3: “...I'm an SNI Level III holder, right? The university, like other private universities, wants... me to go... to sell the programs offered by them. Ok, then they send me to a Model of United Nations in some middle school. I don't... I don't [usually] have contact with middle school teenagers, [and] I don't know what to tell them. And it's like... mmmh ... to what end? I mean... instead of sending me to, I don't know, to a business chamber, or whatever, where I can really make an impact, instead they send me to 13 -14-year-old teens."

In this category, the lowest frequency subcategory was depersonalization. The researchers' perception is that the circumstances in their work place have led them to harden emotionally. However, the three affirmative answers in this subcategory were associated with different factors. The first researcher said this was due to excess work, lack of time, and the poor academic situation of new students. Another one said it was a consequence of the work environment she perceived as hostile against which she has to maintain a defensive attitude. Finally, the last researcher said there was a difference between emotional hardening and strength as a consequence of experiences in her work place.

E3: "Yes, I think so... sometimes, I mean, it is necessary to set limits, isn't it? ...I have to show that I am not going to allow them to marginalize [me] ... the attacks are not constant, but yes, sometimes there are attacks and, ... if someone confronts me I don't keep quiet."

E5: "I do not doubt it. I mean, I have no doubt that sometimes there have been difficult situations but... we don't have to mistake harshness with, say, strength". 
Finally, under this burnout category, along the line of handling a situation, they mentioned getting away from the source causing it; setting limits in the workspace; and doing exercise. Their answers were:

E2: “...I do yoga, or [perhaps] on weekends I don't do anything, anything related with work. I mean I don't even check my e-mails and I don't care if the world at work collapses... I have tried to set limits in the work place because at the end of the day I realize it doesn't work either way."

E3: "...I have tried a little bit to get away from the university and search for a project, something of my interest, or read or... or I take a week off for vacation."

\section{Mobbing}

The results acquired display a high frequency in the social rejection subcategory sometimes coupled with becoming the target of uninvited criticism. These circumstances, seldom as might occur, have raised feelings of anger and embarrassment. In most cases the situation has been sparked by other female colleagues, though in only one case by a male manager. It should be noted that the researchers who had become targets of criticism, sometimes accompanied by attacks on part of other female colleagues, described the offender as troubled and with personal issues. Some researchers' answers are:

E5: "I think that in many places and... especially in the research area where everyone feels like a "god" and "the best" ... this would [often] happen with this colleague - she no longer works here; she thought I was a big problem and then she used to attack me all the time, not directly, but she did attack me...".

E6: "Yes, many times... It has come, well, from the managers. Not my boss but the managers above him... and at some point this was critical to my career. That was when they appointed me as the coordinator of the area and the criticism was now by my colleagues... but it was because of the way that appointment occurred. After a while... they realized or noticed they were mistaken... the situation eventually got resolved and they finally supported me; but at the beginning it was very tough...".

As regards why such criticism sprung, the researchers put it down firstly to jealousy - professional and personal envy; secondly as an attack - or a form of punishment; and finally as a result of miscommunication which led to tension and attacks. The researchers had this to say:

E1: "But I felt there was... jealousy, unfortunately, professional envy, because she [had] always wanted to be a researcher".

E6: "...but by the way in which they gave me such an appointment. After a while... they understood and noticed that they were mistaken... the situation was resolved and they supported me. But at the beginning it was very harsh...". 
In addition, they said that the way to deal with situations like these was to confront the person in the first place, and in some occasions go with an authority or colleague to resolve the situation.

E1: "... "I consider you a bully" I told her and gave her an article on mobbing and bullying at work. Because it seems that, well, I mean, it is a person...".

E3: "...I went and spoke with the dean. I told him, "You know what? Those things are wrong..." Then the situation became less tense".

A lower frequency in the subcategory of social rejection was observed to come in some forms of isolation resulting from laboral psychological harassment. In one instance this behavior was clearly identified and the researcher thinks it was due to her status as a female in a predominantly male field. Furthermore, some researchers mentioned having felt isolated or having been isolated though under different circumstances. First of all, the excessive workload forced her to seclude herself so as to catch up with her work, while the other one decided to withdraw with no apparent reason. They commented as follows:

E3: "...when I started working here... I was the only woman in this area... So, for example, I was in the office at the beginning and they didn't even give me a computer. So I thought "and how am I going to work? Erm... then as I was the only woman here, they never invited to eat, ... until other women from other departments saw me and invited me, that was when I got out of isolation".

E1: "Er, suddenly... there was like an attitude of some people who go out to eat and I know that they often didn't mention it to me, but it was because I really have to isolate myself due to the excess of work I have. But we had a very good relation, yes, yes, yes".

Finally, within this category and the subcategory of social neglect, a lesser frequency was found in professional discouragement. In this scenario, there are no specific telltale behaviors. However, their work has been utterly ignored and public recognition shadowed.

E3: "Erm... no, no, not discouraged. It would be too complicated. Erm... neglected maybe...".

\section{Work-family integration}

On the matter of work-family integration, the descriptor with the highest frequency was family support. The researchers reported they had felt the support of their families, parents, sons and husbands or partners in a variety of manners, all the way from the understanding and adaptation of their children to their schedule and work activities, to the recognition from their parents, partners and children. In addition, the researchers reported that they had the 
aid of maids, either cooking, doing housework or looking after their children as while at work. Some of the answers were:

E4: "My children fully support me and bear all this. I mean ... right now I am answering very calmly; I know that they have also suffered... yes, they have adapted to the circumstances, children are divine, aren't they? Then they adapt to everything."

E6: "Yes, a 100\%. Well, this... Well as I said a while ago, my motherin-law was really important at that time, especially because I lived very peacefully while my son was young because I knew he was with her. ...my parents have encouraged me to develop professionally".

Next, the descriptor that has the lowest frequency is the lack of policies in the institution where they work, belonging to the sub category of conflict. The researchers mentioned that there are no explicit policies. However, they agree that, in some noteworthy cases, exceptions had been made enabling them to perform well in their workplace and especially when their sons and daughters were very young. In addition, they said there should be policies that facilitate integration between work and family by providing more vacation days, days off for individuals working in confined spaces with pollutants such as in laboratories and, finally, policies that include activities to enable them to handle work stress. Below are the answers they advanced in this regard:

E3: "According to the rules of this institution we can't, there is no such possibility. But on a daily basis they allow us, it is possible, yes. ...So in that sense they are not official, but unofficially yes".

E5: "Well no, no. ... I think yes, I believe there should be these policies and not just that but there should also be a review regarding the activities in which we are involved. Someone who is in a laboratory contaminated with solvents, should have at least a few periods of... time off when they could get away from that [situation] more often... maybe longer, I don't know."

Regarding the neglect of family together with social activities due to laboral demands, the results show that this descriptor is presented with a high frequency while the children of the researchers were young. They said that the assistance they had for this to happen was very important so they could continue with their job. They mentioned some of the people who had helped them like their mother, mother-in-law as well as maids who supported them by looking after their children. At present, the situation is different as most of their children are independent adults and those complications have vanished. Below the answers of the researchers:

E1: "Look, now it is very easy because you're interviewing me when my son and my daughter are grownups. But I've always worked; my children were almost born at the university where I work. So at that time I was able to do it... well, with much effort, with plenty of effort". 
E4: "Now no because my sons are independent. But when they were little, yes... because I had to... to pick them up from school, take them to eat at the house and get back to work. Erm, I mean you get used to it. But now that I see it from far away, ..., it was a lot of work”.

According to the results gathered, the descriptor that follows with greater frequency is the flexibility and satisfaction with working hours. Different issues that concern this subcategory were found. First of all, most of the researchers have children over the 18, and in only one case the son was found to be under 18 . It can be said that the various stages in the life of the researchers was extremely relevant in this category.

E1: "Yes, I believe so. Because my family needs are less now, I am always involved with my son and daughter".

E2: "No, no, there is no balance. Because at the end I have little time to take care of my house or to be at home or... to have a little peace of mind. Then I guess not, the balance is not achieved".

E6: "An equilibrium? I would say no. The balance is inclined to the laboral area".

Secondly, the researchers reported that there are two schedules in their workplace, namely the official, which is the one the institution says they have to work, and the unofficial, which is the amount of hours they actually work. They said that, in spite of having to work longer hours than those stipulated, in many occasions they had some flexibility from the institution in their schedule and they perceived that as commitment. Finally, they feel lucky to have such flexibility allowing them to combine their responsibilities as mothers and those at work.

E1: "...we have to work forty-four hours a week. ...I try to fulfill them completely and, also, it is good for me because, as a woman, I don't think I can work at home. ...So, it is a pretty decent schedule, except for Mondays and Wednesdays."

E6: "The official [schedule] is from 8 am to $5 \mathrm{pm}$ and the real one, let's say, is like 9 am until I leave, normally around 8 pm, I mean I work longer hours than I should... I take two hours for lunch... Good news is that they give me plenty of flexibility. ... they give us enough freedom. They do not check what time we arrive or at what time we leave".

The next descriptor refers to the integration or organization of activities together with hours at work and family. First, the researcher with a young son says her organization revolves around his son's schedule. As for the rest of the researchers, it is relatively easy because, from Monday through Friday, their time and attention is devoted exclusively to their responsibilities in their field of work and the weekends are to be spent with their families.

E2: "Well, after I leave my son at school I go to work and I pick him up when I leave work". 
E4: “...Now I can say it is easy. My son is entirely independent ...but when they were young, it was very difficult to do anything. "

\section{Gender}

The results in this category show that the highest frequency is allocated in the subcategory of stereotypes in terms of being a female at SNI. Negative stereotypes are obvious in most cases. The researchers perceive that the fact that they belong to the SNI is not taken into consideration, especially because many people within educational institutions are unaware of the existence of this aspect. However, for the members of the SNI, being a researcher is a symbol of prestige. In addition, they said that many times women within SNI are considered less capable than men and their contributions are not applauded in kind. Also, they think they have been negatively stereotyped as ambitious women for pursuing higher positions at SNI. Otherwise, regarding the aspect of being a woman in the workplace, they perceive there are situations in which people in their field consider preposterous that a woman has a $\mathrm{PhD}$ degree or even a job outside their house. This situation is different for men in the same areas. At their workplace, a lot of people, when they see a woman, they refer to them as "Mrs." or "Miss" and when they see a man they refer to them as "Professor" or "Doctor". The researchers said the following about this:

E1: “... people usually believe... when they see me for the first time ... they never assume that I study or that I have a job and if they think I do, they assume I have a job teaching languages or something like that... they assume, that as a woman, I am a housewife and nothing more, that I have nothing to do or that I am there on my way shopping or who knows what... that is what I see here".

E4: "No, not in the department of chemistry. But let me tell you about the engineering area... erm... Yes, yes, yes it is... well, I haven't seen it but they have told me. They say there is envy and attacks on women because of their brilliance... men... because well... they have crazy ideas about women. Because they have not reached the upper levels at SNI or because they have a lower level at SNI than their women colleagues".

E5: "I think that... the generation of men that have a lot of representation in the qualifiers group have... strong issues of aggressiveness and dominance over women. I know many of the qualifiers and I don't have any problem with them at the workplace, but when they are together, then they change. I believe... that is... I mean they say things like, "hey, it is a woman, let's see what she did..." just for being a woman ... [the prejudice is] "let's see if she can do it".

In second place is the sub-category of equity with the descriptor of gender inequality or gender discrimination. The researchers refer to issues such as the glass ceiling, income inequality and inequality of opportunities. 
E1: "What I see here at the university is the famous ... glass ceiling. In this university... you can go to the Dean's office and there are women everywhere working and studying ... but then you get to a certain level and there are just men, men everywhere and no women. I believe that...that is very unfortunate...".

E3: "I think that there are more opportunities for men... There is also an earnings gap; men have better salaries... I believe that, right now, here, not so much at the university, but in general, that is a reality...".

Finally, regarding the subcategory of division by gender, the majority felt their fields were female-inclusive except in the area of political science that was considered a "men-only area". It should be noted that the researcher working in this academic field recalls facing different setbacks due to this situation. Also, it is not well taken that women in "female fields" work on "male" projects and they are criticized strongly because of this.

E3: "Yes it is predominantly male. Yes... in fact, when I started... I remember the first few times I went to a congress of international relations and there were just men and around 10 women, something like that, horrible."

E5: "Well, uh, here is predominantly female but not necessarily in industry. It is difficult, it is very difficult but I do not [intend to] change or have fear... because they are... I wouldn't say manly, but they are machos (laughter) that will do anything to annoy women. ...So women have to work more in that regard..."

In conclusion, the results obtained provided enough information to visualize the situation in the workplace of women researchers who are part of the SNI. Without making a generalization of the results acquired, it is recommended to make pertinent changes leading to a better performance and fulfillment of the mission of CONACYT, which is to produce high-quality scientific knowledge to improve the quality of life and well-being of Mexicans.

\section{Conclusion}

In this preliminary investigation, it is evident that the role of women is changing. It can be observed that two main areas are being affected, to wit workplace and family. In addition, men and women can perceive these two areas differently as a result. It can be concluded that it is essential to carry out studies of psychosocial work factors with a gender-oriented perspective to assess and intervene in order to create policies to promote academic and professional equality at SNI, so it continues to create healthier organizations and societies.

Finally, it is imperative to close the gap between the number of women and men at SNI as well as to create and implement policies to reconcile work 
with familial areas and eliminate family stereotypes through education and training in gender equality, including positive actions to generate such conciliation.

Finally, it is imperative to close the gap between the number of women and the number of men who belong to the SNI; as well as, to create and implement policies to reconcile work with family areas and eliminate stereotypes about family through education and training in gender equality, including positive actions to generate such conciliation.

\section{References:}

1. Cárdenas, M. La Participación De Las Mujeres Investigadoras En México. Investigación Administrativa [en línea] 2015, 44. Recuperado el 3-02-17 de http://9www.redalyc.org/articulo.oa?id=456044959004

2. Díaz, C., Bulnes, M., Tovar, J., Pisco, M. y Huertas, R. (2005). El síndrome del" quemado" por estrés laboral asistencial en grupos de docentes universitarios. Revista de investigación en psicología, 8(2), $87-112$.

3. Greenhaus, J., Collins, K. y Shaw, J. (2003). The relation between work-family balance and quality of life. Journal of vocational behavior, 63(3), 510-531.

4. Guevara, R., Medel, E. y García, C. (2012). Las académicas como modelo para dedicarse a la investigación en estudiantes de psicología. Revista Mexicana de Orientación Educativa, 9(23), 36-42. Recuperado el

26-02-18,de http://pepsic.bvsalud.org/scielo.php?script=sci_arttext\&pid=S1665$75272012000200006 \& \operatorname{lng}=$ pt\&tlng=es.

5. Hernández, R. (2010). Metodología de la Investigación, Quinta Edición. McGRAW-Hill Interamericana.

6. Lamas, M. (1986). La antropología feminista y la categoría" género". Nueva Antropología. Revista de Ciencias Sociales, (30), 173-198.

7. Mendoza, E. (2015). Principales logros y desafíos del Sistema Nacional de Investigadores de México a 30 años de su creación. Revista CTS, 10(28).

8. Silla, J. (2001). El estrés laboral: una perspectiva individual y colectiva. Prevención, trabajo y salud: Revista del Instituto Nacional de Seguridad e Higiene en el trabajo, (13), 18, 38.

9. Trujillo, M., Almegua, V., de la Luz, M., y Hernández, R. (2007). Mobbing: history, causes, effects and proposal for a model for Mexican organizations. Innovar, 17(29), 71-92.

10. Foro Consultivo Científico y Tecnológico (FCCYT). (2016). El Sistema Nacional de Investigadores en Números. Recuperado el 2602-18

de, 
http://www.foroconsultivo.org.mx/FCCyT/sites/default/files/SNI_en_ numeros.pdf

11. Grupo Banco Mundial. (2014). Recuperado el 08-09-2016 en, http://datos.bancomundial.org/indicador/SL.TLF.CACT.FE.ZS?locati ons $=\mathrm{MX}$

12. Instituto Nacional de Estadística y Geografía (INEGI). (2015). Recuperado el 09-09-2016 en, http://www.inegi.org.mx/sistemas/bie/ 